\title{
Racial Profiling in the Medical School Curriculum
}

\section{SOPHIE GUÉNIN [D}

*Author affiliations can be found in the back matter of this article
凹

Levy

Library

Press

\section{ABSTRACT}

In medical school, we are taught the differential diagnosis: to rule things in and rule things out based on how likely or unlikely a disease, syndrome, or condition may be in an individual. In class and in preparation for board exams, we are taught to suspect malaria or sickle cell disease in a Black patient, nasopharyngeal carcinoma caused by Epstein-Barr Virus in a Chinese man, or a lysosomal storage disease in Ashkenazi Jewish descendant. While I do not doubt the prevalence of certain diseases and conditions in some populations, I find myself questioning whether or not memorizing these associations is the correct way to go about my medical education and learning to form a differential diagnosis. It seems that we are pushed to develop reflex reactions to certain conditions, situations, or buzzwords. If we are influenced by our education to slap "likely" diagnosis on certain populations, do we not run the risk of missing the less prevalent "real" diagnosis? We may also run the risk of insidious propagation of implicit bias among newly trained physicians.

Further, in 2020 with globalization and the extensive movement of people and goods, is it still accurate to teach students to suspect various diseases based on a person's ethnic background, race, or sexual orientation? For example, studies have shown that for diagnoses such as cancer where environmental factors play a major role, cancer profiles of immigrant individuals begin to more closely mirror that of their new country rather than their former one. With the anti-vaxxer movement in the United States, should we not suspect a measles infection to be as likely in a White American child as in a generic "immigrant" child, such as the ones presented in exam questions and textbooks?

To say there is much to learn in medical school would be an understatement and to say that it is easy to teach medicine to medical students would be an even larger one. However, the racial profiling that we are taught in patient cases has become increasingly apparent and warrants discussion. 
COMPETING INTERESTS

The author has no competing interests to declare.
ISMMS Journal of Science

and Medicine

DOI: $10.29024 /$ ijsm. 39

\section{AUTHOR AFFILIATION}

Sophie Guénin (D) orcid.org/0000-0002-0161-5723

New York Medical College, US

TO CITE THIS ARTICLE:

Guénin S. Racial Profiling in the Medical School Curriculum. ISMMS Journal of Science and Medicine. 2021; 1(1): 9, pp. 1-2. DOI: https://doi. org/10.29024/ijsm.39

Submitted: 21 December 2020 Accepted: 21 December 2020

Published: 22 January 2021

COPYRIGHT:

(c) 2021 The Author(s). This is an open-access article distributed under the terms of the Creative Commons Attribution 4.0 International License (CC-BY 4.0), which permits unrestricted use, distribution, and reproduction in any medium, provided the original author and source are credited. See http://creativecommons.org/ licenses/by/4.0/.

ISMMS Journal of Science and Medicine is a peer-reviewed open access journal published by Levy Library Press. 